\title{
Transatlantica
}

Revue d'études américaines. American Studies Journal

\section{Introduction to some "further adventures into the restless universe" of contemporary American fiction}

Brigitte Félix

\section{(2) OpenEdition \\ 1 Journals}

Electronic version

URL: https://journals.openedition.org/transatlantica/5087

DOI: 10.4000/transatlantica.5087

ISSN: $1765-2766$

Publisher

Association française d'Etudes Américaines (AFEA)

\section{Electronic reference}

Brigitte Félix, "Introduction to some "further adventures into the restless universe" of contemporary American fiction", Transatlantica [Online], 2 | 2010, Online since 12 April 2011, connection on 31

January 2023. URL: http://journals.openedition.org/transatlantica/5087 ; DOI: https://doi.org/ 10.4000/transatlantica.5087

This text was automatically generated on 31 January 2023.

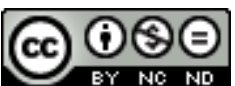

Creative Commons - Attribution-NonCommercial-NoDerivatives 4.0 International - CC BY-NC-ND 4.0 https://creativecommons.org/licenses/by-nc-nd/4.0/ 


\title{
Introduction to some "further adventures into the restless universe" 1 of contemporary American fiction
}

\author{
Brigitte Félix
}

1 The present selection is composed of three articles (on Dawn Raffel, Shelley Jackson and Matthew Derby) and an interview of Dawn Raffel conducted by Monica Manolescu. Those texts are part of the collective ongoing project of French researchers in American literature who, for the past four decades, have been exploring the ceaselessly expanding galaxy of what is somewhat loosely termed "contemporary American fiction".

2 The composition of this dossier, entitled "New American Voices", raises some legitimate questions: why bring together Dawn Raffel, Matthew Derby and Shelley Jackson? How "new" are they and how are they "new"? The following comments will try to provide a few answers, add a few more questions, while introducing each of the three critical contributions, respectively by Monica Manolescu, Arnaud Regnauld and Stéphane Vanderhaeghe.

4 The three writers under consideration can hardly be considered "new voices", if what "new" suggests is only "(very) recent". Dawn Raffel's first collection, In the Year of Long Division, came out in 1994, and Shelley Jackson's first work, the acclaimed hypertext novel Patchwork Girl, dates from 1995. Jackson first print publication, a collection of stories entitled The Melancholy of Anatomy, came out in 2002, the same year as Matthew Derby's one and only published book so far, Super Flat Times. But what's in references to dates, anyway, except some weak form of ordering? It is certainly not sufficient to base the definition of the new and the contemporary on matters of time periods. Every generation, every writer or critic, may fix different starting points. "When does the contemporary begin ?" is a vexing and vexed question, as Lionel Ruffel demonstrates in 
his stimulating introductory essay to the collective volume he edited, Qu'est-ce que le contemporain ?. ${ }^{2}$

5 "New" can also be used in an aesthetic sense to designate "innovative" writing. However, just as the notion of "contemporary" is problematic when you try to turn it into a defining category of some sort, the "innovative" dimension seems to be too quickly subsumed in the critical representations of the contemporary, while the exact nature of the innovation is left unexplored and its workings unexplained.

6 The three articles of this dossier share an underlying assumption: the contemporary writers under study more or less explicitly raise the issue of how to read the fictions they are writing. With some variations from one author to the next, the suggestion is that the innovation lies not only in the writing itself, but also in the challenging of the act of reading itself which is inscribed within the fiction. Each article deals with that matter of "how to read"-rethinking intertextuality as a way of reading (Manolescu); examining the narrative techniques that foreground the "impossible construction of reality through fiction as it destroys the very possibility of meaning and [...] prevents any hermeneutic approach" (Regnauld, on Derby's Super Flat Times); shaking the foundations of the hermeneutics of reading in the radical (im)possibility of (un)reading (as shown by Vanderhaeghe in "How to Unread Shelley Jackson?").

7 In Raffel's Carrying the Body and In the Year of Long Division, the reader "needs to find a way of his own in an uncharted territory of implied references and affinities", which leads M. Manolescu to devise a new kind of intertextual approach-which she calls "intuitionist" in her interview with Raffel-in order to "make sense of a certain practice of writing" that is seemingly "a-intertextual". The carried body of Raffel's novel is "a metaphoric framework for both the writer's relationship with literary memory and Dawn Raffel's own vision of the use of language as substance, as organic matter, as creation of a new body of words". But "carrying the body" could also refer to the reader's activity, to the weight of her own references without which the book could not be read. "Trust the reader", Dawn Raffel learnt from her mentor Gordon Lish (see interview). Trust your reading, Manolescu seems to imply, for as Tony Tanner remarked, "when we are reading a book from the past we are in fact reading a book and a context, but in reading a book from the present we are the context". ${ }^{3}$

8 One essential feature of contemporary American writing, according to Patrick O'Donnell, is that "no matter how 'realistic' or 'metafictional' the work may be, on some level, it is attentive to and reflective about its status as a construction of language". ${ }^{4}$ Arnaud Regnauld first presents Super Flat Times as a takeoff on the topoi of some classics of science fiction, "pointing out the limits of the genre itself", but "Derby's tinkering with the codes of science fiction bears indeed a more radical ambition as it undermines the very grounds of reference" through a general process of "flattening out", for instance in the abrasion of all potentially metaphorical meaning. The stories "interrogate the very possibility of a relation to be understood both in the sense of kinship, that which cements a community, as well as the weaving of a narrative". Because of the accumulation of devices-such as the privileging of metonymy-that produce "a disturbing leveling off effect which [...] prevents any hermeneutic approach", the "relation" of the reader to the text is also strained, and as A. Regnauld suggests, the reader will then attempt to "reduce" the text's otherness by trying "to thread back narrative strands into a continuous and coherent whole". Thus 
Super Flat Times also ironically includes within its "leveling off" strategies the temptation of the "super flat" reading...

9 Shelley Jackson's fiction challenges the idea that reading results in inevitable gain without loss. In the writing of his own critical examination of Jackson's Half Life, S. Vanderhaeghe makes it obvious that it is the existence and the significance of both entities, text and reader, that are at stake in the very act of reading the text. Going from black to white, from Nora to Blanche (the dual, and/or double, Siamese characternarrator), Half Life is best described as an "unbook that somehow unwrites itself and that, ultimately, the 'reader' (whatever that antiquated term refers to) needs to unread". Jackson's novel reaches the outer limits of writing when at the end only punctuation marks remain on a "stained", blank page. The whole narrative appears to "covet the blankness of the page, as though writing were not so much concerned with blackening the page as erasing it, or rubbing it clean". Does that imply that after the death of the author we should now contemplate the death of the reader-"whose epitaph", Vanderhaeghe declares, "Shelley Jackson's work as a whole [...] may be meticulously spelling out"? Actually, the narrative's system of binary oppositions not only produces a "new writing/reading experience, essentially defined by what the text is not", it also generates an endlessly reversible text. "Half" of the "life" is in the writing and the book, the other half is in its reading. You cannot read Half Life without "unreading" it, just as the book "un-ends" only to allow for its immediate rereading, which should logically be a "re-unreading" of the novel. "Again", concludes Vanderhaeghe.

11 It is time for the readers to take over, as the narrator at the end of Super Flat Times hopes they will, "to continue this work". Or, to quote a representative of the previous generation of innovators, Thomas Pynchon's final rallying and powerful "un-ending" of Gravity's Rainbow: "Now everybody-".

12 This dossier, which presents only a fraction of that "restless universe" of contemporary American fiction, can be read as a complement to the collection of critical essays edited by Jean-Yves Pellegrin and published in the April-June 2010 issue of Études anglaises. In addition to analyses of some of today's innovative but "invisible" authors whose "genuinely new voices [are] heard only on the low frequencies of the American literary spectrum" $(133)^{5}$, J.-Y. Pellegrin has compiled an extremely valuable bibliography of recent critical works-books, essays and interviews-concerned with narrative innovation and contemporary fiction since the 1980 s.

\section{NOTES}

1. I borrow the title of Dawn Raffel's latest story collection (published in 2010 by Dzanc Books).

2. Nantes, Editions Cécile Defaut, 2010.

3. In Scenes of Nature, Signs of Men, Cambridge, Cambridge University Press, 1987, 176.

4. The American Novel Now: Reading Contemporary American Fiction since 1980, Oxford, WileyBlackwell, 2010, 20. 
5. Invisibility, that is, in the eyes of the more commercial publishing industry and "mediadazed" general environment (including part of the reading public). In his seminal essay on Ben Marcus's The Age of Wire and String, Marc Chénetier underlines the polar opposition between "art that takes language seriously, as the vital/lethal thing it is" and the "more conventional and more enthusiastically hailed literary productions of our lazy, media-dazed, ready-to-think, kneejerk correct times" (“'Ostranenye Goes Gevortsing,' or, 'the Dethompsoning of Quiddity': an Eyewitness Report”, Revue Française d'Études Américaines, n73, juin 1997, 83).

\section{AUTHOR}

\section{BRIGITTE FÉLIX}

Université du Maine 